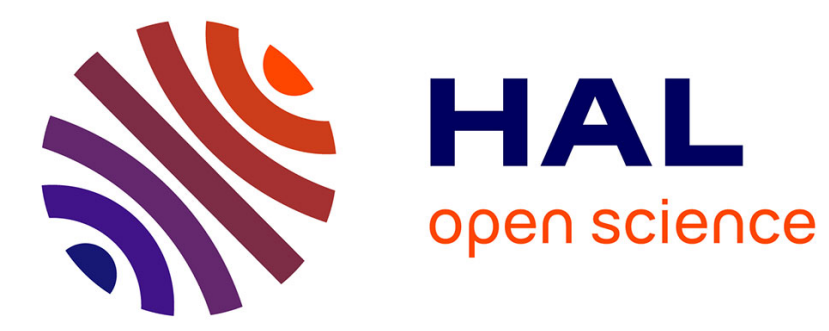

\title{
How French Learners of Chinese L2 Express Motion Events in Narratives
}

\author{
Arnaud Arslangul
}

\section{To cite this version:}

Arnaud Arslangul. How French Learners of Chinese L2 Express Motion Events in Narratives. Dan XU \& Jingqi FU. Space and Quantification in Languages of China, , 2015, 978-3-319-10039-5. 10.1007/978-3-319-10040-1_9. hal-01354811

\section{HAL Id: hal-01354811 https://hal.science/hal-01354811}

Submitted on 22 Aug 2016

HAL is a multi-disciplinary open access archive for the deposit and dissemination of scientific research documents, whether they are published or not. The documents may come from teaching and research institutions in France or abroad, or from public or private research centers.
L'archive ouverte pluridisciplinaire HAL, est destinée au dépôt et à la diffusion de documents scientifiques de niveau recherche, publiés ou non, émanant des établissements d'enseignement et de recherche français ou étrangers, des laboratoires publics ou privés. 


\title{
How French Learners of Chinese L2 Express Motion Events in Narratives
}

\author{
Arnaud Arslangul*
}

\begin{abstract}
The present study examines the ways in which French intermediate learners of Mandarin Chinese express motion events in the framework of event conflation proposed by Talmy $(1985,1991,2000 \mathrm{~b})$. The procedure used is the analysis of an oral corpus of French L2 learners of Chinese and adult native Chinese and French speakers consisting of a verbal production task based on the wordless picture book "Frog, where are you?". This analysis was carried out at three levels. At the conceptual level, the results reveal that L2 learners, like French L1 speakers, express more static and less dynamic relations than Chinese L1 speakers. At the semantic and linguistic levels, the results show that L2 learners' clauses were semantically less dense than those of Chinese L1 speakers; the former also express more Path and less Manner and Cause than the latter and the linguistic components chosen to express those semantic components are also different. These findings suggest that the difference between Chinese L1 speakers and L2 learners occurs at the conceptualization level (Levelt 1989).
\end{abstract}

\section{Keywords}

Motion events, narrative discourse, corpus analysis, second language acquisition, cognitive semantics, Mandarin Chinese

\section{Introduction}

Over the last few decades, a growing number of studies have examined the domain of space in various disciplines such as cognitive sciences, language typology, and language acquisition (see Berman and Slobin 1994; Bloom et al. 1996; Becker and Carroll 1997; Levinson 2003; Levinson and Wilkins 2006; Hickmann and Robert 2006). Space is traditionally considered to be one of the most basic domains of human cognition, but despite similar conceptualization, narrating a motion event can take different forms, and there are wide variations across languages. The well-known typology of motion events proposed by Talmy $(1985,1991,2000 \mathrm{~b})$ suggests that languages can be classified into two categories according to which linguistic component encodes the Path semantic component of the motion, the verb (verb-framed languages) or the satellite (satellite-framed languages). His theory suggests that French belongs to the former category and Chinese belongs to the latter one. 
From a language typology point of view, our first goal is to show how these two languages actually differ in the way they express motion events in narratives. We will describe the overall patterns characterizing the distribution of semantic components of motion events in French and Chinese L1 and investigate how they differ in encoding dynamic predicates: which semantic components are actually selected and which linguistic components are used to do so. We will then look at how French intermediate learners of Mandarin Chinese deal with those differences and restructure their "thinking for speaking" (Slobin 1987, 1996a). Our hypothesis is that L2 learners rely very heavily on how motion events are structured in their L1, which should be seen at the conceptualization level during speech production (Levelt 1989).

The procedure used is the analysis of an oral corpus of French L2 learners of Chinese and adult native Chinese and French speakers comprising a verbal production task. The discourse produced is a narrative based on the wordless picture book "Frog, where are you?".

The analysis was carried out at three levels. At the conceptual level, we analyzed in which proportions the different kinds of spatial relations were used to retell the story. At the semantic level, we looked at the proportions in which the several semantic components were used (information Focus). At the linguistic level, we looked at which linguistic components encoded these semantic components (information Locus), and how the semantic components were packaged together into clauses (information density and packaging) (Hickmann and Hendriks 2010; Ji et al. 2011).

Section 2 below first provides a brief description of Talmy's motion event typology and how Chinese and French are categorized in this framework. Section 3 reviews Levelt's discourse production model to be used in this work. Section 4 then presents the methodology of the study, including participants, stimuli and procedure, data coding, followed by our research questions and hypotheses. The main results of the study are reported and discussed in detail in Sects. 5 and 6.

\section{Motion Events}

\subsection{Talmy's Motion-Framing Typology}

The theory developed by Leonard Talmy $(1985,1991,2000 b)$ identifies two types of components: semantic and linguistic. The former includes: Motion, Figure, Ground, Path, Manner and Cause; the latter are: verbs, adpositions, subordinate clauses and satellites. Talmy's central objective is to understand how semantic components are encoded in the linguistic components to form complex events (composed of a framing event and co-events); what he refers to as "the lexicalization process". 
The type of event which will be of particular interest to us is the Motion event. It is an event of physical motion or stationariness, in which the motion or location of a salient figural entity (Figure) is related to a background referenceobject (Ground). Talmy (1991: 486) proposes a typology of languages based on the kind of linguistic component which expresses the framing event (core schema): "Languages that characteristically map the core schema into the verb will be said to have a framing verb and to be verb-framed languages", like French and Spanish; "languages that characteristically map the core schema onto the satellite will be said to have a framing satellite and to be satellite-framed languages", like English or Chinese.

In satellite-framed languages (S-languages), the co-event is expressed by a verb and the framing event by a satellite (Talmy 1985: 62):

\begin{tabular}{|c|c|c|c|c|}
\hline $\begin{array}{l}\text { (1) The rock } \\
\text { noun }\end{array}$ & $\begin{array}{l}\text { rolled } \\
\text { verb }\end{array}$ & $\begin{array}{l}\text { down } \\
\text { satellite }\end{array}$ & $\begin{array}{l}\text { the hill } \\
\text { noun }\end{array}$ & \\
\hline Figure & Motion + Manner & Path & Ground & \\
\hline $\begin{array}{l}\text { (2) I } \\
\text { noun }\end{array}$ & $\begin{array}{l}\text { pushed } \\
\text { verb }\end{array}$ & $\begin{array}{l}\text { the keg } \\
\text { noun }\end{array}$ & $\begin{array}{l}\text { into } \\
\text { satellite }\end{array}$ & $\begin{array}{l}\text { the storeroom } \\
\text { noun }\end{array}$ \\
\hline Agent & Motion + Cause & Figure & Path & Ground \\
\hline
\end{tabular}

In verb-framed languages ( $\mathrm{V}$-languages), the framing event is expressed by a verb and the co-event in an adjunct like adverbial, gerund, etc. (Talmy 1985: 69):

$\begin{array}{llll}\text { (3) La botella } & \text { entró } & \text { a la cueva } & \text { (flotando) } \\ \text { The bottle } & \text { moved-in } & \text { to the cave } & \text { (floating) } \\ \text { noun } & \text { verb } & \text { PP } & \text { (gerund) } \\ \text { Figure } & \text { Motion + Path } & \text { Ground } & \text { (Manner) }\end{array}$

"The bottle floated into the cave."

In his first publication, Talmy (1985) does not make any distinction between the kind of motion where the Figure changes location with respect to the Ground, and a situation containing movement, where the Figure is moving inside the Ground. This has been criticized by several scholars (Aske 1989; Slobin and Hoiting 1994; Slobin 1997). Subsequently, Talmy (2000b: 35) made an adjustment in this respect, dividing motion events into translational motion, where "an object's basic location shifts from one point to another in space", selfcontained motion, where "an object keeps its same basic, or 'average' location", on the one hand, and location, where "the Figure stays fixed with respect to the Ground", on the other hand. Those spatial relations are called change of location, general dynamic location, and general static location by Hendricks (1998). We will use this terminology in this article. 


\subsection{Chinese in Talmy's Typology}

Talmy considers Chinese to be an S-language ${ }^{1}$, the framing-event being encoded in a satellite (上 shàng “up”, 下 xià “down”, 去 qù “thither”, 走 zǒu “away”...) and the co-events being encoded in the verb. This is what is referred to in Chinese traditional grammar as directional resultatives and attainment resultatives (Packard 2000). The information packaging would be for example:

(4)

$\begin{array}{lll}飞 & \text { 进 } & \text { 来 } \\ f \bar{e} i & \text { jìn } & \text { lai } \\ \text { fly } & \text { in } & \text { hither } \\ \text { Verb }_{[\text {Manner] }} & \text { Satellite }_{[\text {Path] }} & \text { Satellite } \\ \text { [Path] }\end{array}$

Talmy's dichotomy was challenged by Schaefer (1986), ${ }^{2}$ who seems to have been the first to raise the problem of the Serial Verb Construction (SVC). ${ }^{3}$ According to him, a language like Emai (Nigeria) raises a dilemma by not holding to the assumptions of Talmy's model, since in serial structures two verbs in a single surface level clause are used to refer to a motion event. Thus, the framing event and the co-event would be encoded by the same type of linguistic component. This distribution of information does not exist in Talmy's typology. Several scholars have made the same argument for different languages, for example Slobin and Hoiting (1994) for the 拉祜 Lähù language, spoken by an ethnic minority of Southwest China (Yunnan Province); Ameka and Essegbey (2001) for Ewe and Akan (Kwa languages of West Africa), Zlatev and Yangklang (2003) for the Thai language, as well as Senft (2006) for the Kilivila language (an Austronesian language of Papua New Guinea). They all propose that those languages cannot be said to belong the V-languages or S-languages, but instead appear to belong to a class of their own and should be explicitly recognized in Talmy's typology. To fill this gap, Slobin $(2000,2004)$ proposed adding a third type of language in Talmy's typology called Equipollently-framed languages to include serial verb construction languages (SVC) in which both Manner and Path are expressed by elements that are equal in formal linguistic terms, and appear to be equal in force or significance. There are strong proponents of this theory for Mandarin Chinese, namely Chen 2005; Chen and Guo 2009; Chen and Guo 2010.

\footnotetext{
${ }^{1}$ Talmy (1985: 106, 114; 1991: 486; 2000 vol 1: 222; 2000 vol 2: 60, 102, 103, 109).

${ }^{2}$ Quoted by Ameka and Essegbey (2006: 394)

${ }^{3}$ According to Aikhenvald and Dixon (2006: 1), a serial verb construction is a sequence of verbs which act together as a single predicate, without any overt marker of coordination, subordination, or syntactic dependency of any other sort. Serial verb constructions describe what is conceptualized as a single event. They are monoclausal; their intonational properties are the same as those of a monoverbal clause, and they have just one tense, aspect, and polarity value. SVCs may also share core and other arguments. Each component of an SVC must be able to occur on its own. Within an SVC; the individual verbs may have same, or different, transitivity values.
} 
In Chinese linguistics, the serial verb construction, since its first appearance in Chinese linguistics (Chao 1948), is always described separately from "verb complements" like resultatives (see also Ding 1961; Chao 1968; Lü 1980; Zhu 1982; Li and Thompson 1981). Aikhenvald and Dixon (2006) argue that a serial verb construction is a sequence of verbs without syntactic dependency of any sort. Zhu (1985: 55) or Fan (1998: 69) share this assumption and say that the relation between verbs in SVC cannot be, among others, a verbcomplement relation. There is indeed a diachronic relation between SVC and resultatives. Shi and $\mathrm{Li}$ (2001: 54) and Gao (2003: 156) argue that the latter grammaticalized from the former. Feng (2001) shows that between the Early Medieval period $\left(2^{\text {nd }}-6^{\text {th }}\right.$ centuries $)$ and the late Medieval $\left(7^{\text {th }}-13^{\text {th }}\right.$ centuries $)$ these forms experienced reanalysis, an evolution process of grammaticalization similar to that which gave rise to resultative complements. Liang (2007) provides further arguments to arrive at the same conclusions: structural relationships of these elements were reanalyzed. This was the beginning of the process of grammaticalization of the form that has become the directional complement.

Peyraube (2006) considers Chinese to be an S-language. For him, the directional complements (either simple or complex) might still be considered as verbs, but are obviously no longer fully lexical words with their original meanings. They have become function words or grammatical elements, after having undergone a process of grammaticalization. He considers that around the $10^{\text {th }}$ century, Chinese underwent a structural shift changing from V-language to S-language in terms of mapping the complex event conceptual structure onto its syntactic surface form. ${ }^{4}$ Lamarre (2007) is also a proponent of the idea that directional complements have grammaticalized into satellites, and provides several arguments in its support: (a) directional complements are unstressed syllables, pronounced in the same prosodic unit as the co-event verb, neutralization of tonal contrast being a feature regularly linked with grammaticalization in Mandarin Chinese; (b) Path satellites are a closed-class category; (c) a co-event verb can at most take only one (twofold) Directional Satellite, and strict rules constrain the combination of the co-event verb and the Directional complements; (d) deictic verbs in third position have lost their argument structure, they cannot take locative NPs. For all these reasons, we follow these scholars who consider that resultatives are satellites and that Chinese belongs to the S-language category.

\subsection{French in Talmy's Typology}

Pourcel and Kopecka (2005) seek to understand how the motion event's semantic components are encoded in French and where French stands in Talmy's typology. The authors analyze data produced by native speakers ${ }^{5}$ and show that French has a greater diversity than the unique features of the V-language proposed by Talmy.

\footnotetext{
${ }^{4}$ See also Li (1997)

${ }^{5}$ Their corpus consists of two narration tasks: the first is written, based on short video clips (40 informants), and the second is oral, based on a few minutes of the film "City Lights" by Charlie Chaplin (25 informants).
} 
This structure is still prevalent in the productions; however they identified two additional and widely used structures.

In the representative structure of V-languages, the Path semantic component is encoded in the verb. When the co-event appears, it is in an external addition to the verb (a prepositional phrase, an adverb, or gerund):

(5) il

\begin{tabular}{|c|c|c|c|}
\hline il & entre & dans la maison & $\begin{array}{l}\text { sur la pointe des pieds / } \\
\text { précipitamment / en courant }\end{array}$ \\
\hline he & enter & in the house & on tiptoe / hurriedly / running \\
\hline Subject $_{\text {[Figure] }}$ & $\begin{array}{l}\text { Verb [Path] } \\
\text { urries / run }\end{array}$ & Object [Ground] & PP/Adverb/Gerund ${ }_{\text {[Manner] }}$ \\
\hline
\end{tabular}

Pourcel and Kopecka (2005) also show that there are occurrences in French of the representative structure of S-language in two different forms. The co-event is in the verb and the Path is encoded in a satellite, either in a verbal particle or in a prefix:
(6) l'enfant court hors du jardin
the child run garden
Subject $_{\text {[Figure] }}$ Verb ${ }_{\text {[Manner] }}$ Satellite $_{\text {[Path] }}$ Object $_{\text {[Ground] }}$
"The child runs out of the garden."
$\begin{array}{lll}\text { (7) les abeilles } & \text { s'en-volent } & \text { de la ruche } \\ \text { the bees } & \text { away-fly } & \text { hive } \\ \text { Subject }{ }_{\text {[Figure] }} & \text { Satellite }{ }_{[\text {Path]-Verb }}{ }_{\text {[Manner] }} & \text { Object }{ }_{\text {[Ground] }}\end{array}$
"The bees fly away from the hive."

This hybrid structure, characterized by the conflation within the verb of Manner and Path semantic components, reflects the hybrid nature of the French verbal lexicon which, in this aspect, is divided into two categories: compact lexical units ("grimper" climb, "plonger" dive) and fossilized forms including a prefix encoding Path and a verb root encoding Manner ("dégringoler" to tumble, "dégouliner" to trickle).

Kopecka (2004) asserts the existence of two typological strategies in French: a V-language strategy and an S-language strategy. To justify the second, the author shows that prefixes play an essential role in the motion lexicalization pattern; they may express telic translational motion between Figure and Ground. Semantic analysis reveals that the prefixes may encode other semantic components such as Cause, Figure and Ground, which is extremely rare according to the Talmy's typology. In addition, the presentation of the diachronic evolution of prefixes shows that the satellite structure is a remnant of an ancient typology that was dominant in Old French, but which evolved over the centuries into the current conflation, due to loss of productivity of prefixes. In contemporary French, only a few prefixes, for example re- "back" and emlen- "away", are still productive and semantically transparent. In our analyses, we will consider the hybrid structure introduced by Pourcel and Kopecka (2005). 


\section{Discourse Production and Levelt's Model}

Levelt (1989) proposes a discourse production model that details the operations involved in the use of language and how they are organized. The model provides a representation of what happens in the brain of the speaker from the communicative intention to articulation of speech. It represents the oral spontaneous speech of adult speakers. Originally designed for L1 studies, it has also been adapted to L2 analysis (for studies referring to Levelt's model applied to second language acquisition, see for example: Carrol and von Stutterheim 1993 or Watorek 1998). The production process is divided into three macrooperations: (a) conceptualization of the preverbal message, (b) formulation and (c) articulation.

(a) Conceptualization occurs in two stages: macro-planning and microplanning. In the first step, the speaker defines his communicative intention in a sequence of subgoals and selects the information needed to accomplish them. The second step is linearization, which divides the information into smaller conceptual 'chunks' which are given the correct propositional shape and informational perspective. The product of this first macro-operation is what Levelt refers to as the 'preverbal plan'. It is an organized conceptual structure which is not yet linguistic. (b) The second macro-operation is formulation. It consists of the transformation of the conceptual level into the linguistic level with surface structure and a phonological encoding which leads to internal speech. (c) Then, articulation transforms the internal speech into external speech using articulatory organs. The speaker has access to the two levels of speech, and is able to analyze it thanks to his understanding. Finding an error in his speech, he may stop production to return to the preverbal message.

Levelt's model is a valuable contribution to distinguish conceptual and linguistic levels in language production. In the adult monolingual's speech production, the conceptualization of preverbal messages (high level activity) requires constant attention, while operations of formulation and articulation are seen as an automatic process (low level activity). For L2 speakers, automaticity is not a given feature of language production; the partial control of these two operations can potentially disrupt the high level activity. The interaction between these two levels raises the question: to what extent does the grammar of the language affect the selection and organization of information in speech? That is to say: to what extent is the conceptualization of the preverbal message dependent on its linguistic encoding? This relation between "thought" and "language" is reminiscent of the Sapir-Whorf hypothesis of linguistic relativity, which proposes that linguistic categories and usage influence thought and certain kinds of non-linguistic behavior. Slobin (1987, 1996a) proposes a dynamic formulation of this question in terms of "thinking for speaking". He looks at how grammar affects the choice of information to be transmitted and its organization in speech during language production. He suggests that the grammar of a language influences what is expressed more easily and automatically. 


\section{Research Methodology}

This qualitative study tries to provide general tendencies of the typological classification of the two languages involved and of L2 acquisition phenomena demonstrated by French learners of Chinese.

\subsection{Participants}

For this purpose, we gathered 48 participants, divided into 3 groups:

- 16 native Mandarin Chinese speakers (hereafter CL1);

- 12 native French speakers (FL1);

- 16 native French speakers, learners of Chinese as a second language (CL2).

The native Chinese speaker group is composed of 22 to 28 year old students, 8 females and 8 males, from several Chinese universities. Some of them were speakers of other Sinitic languages but had a high education level, and their commonly used language in everyday communication was a very standard Mandarin Chinese. We haven't noticed any dialect influence in their speech. The native French speaker group is composed of 21 to 39 year old students and workers, 4 females and 8 males. This corpus has been collected by de Lorenzo Rosselló (2002). The Chinese learners group is composed of 22 to 45 year old students, 12 females and 4 males. They were all engaged in a Chinese language educational program at the Master's level at one of two French universities for 4 to 7 years. All of them spent time studying in China (from a month to a year). They were what we can call "high education level advanced learners" (Bartning 1997).

\subsection{Stimuli and Procedure}

The present study involved a production task based on Mayer's (1969) wordless picture book "Frog, where are you?" (24 pictures). It tells the story of a boy who has a dog and a pet frog: the frog escapes from its bottle and runs away; the boy and dog look for it near the house, through the woods, and over a cliff, until they find it, and return home with the original pet frog's baby frog. The research method based on this picture book is now commonly known as the frog story method and has been largely used in first and second language acquisition research (Berman and Slobin 1994). The method is simple, but has several advantages (Slobin 2004): because it is wordless, it can be used with speakers of any language without reading interference; the story is easy to understand, independently of cultural background and age; it is composed of a long series of events, all leading to a complex narrative, and invites a rich collection of motion event descriptions. 
It also allows analysis in different referential domains like space, time or entities and offers an excellent source for the cross-linguistic study of motion event descriptions in discourse.

Elicited narratives were collected following the procedures outlined by Berman and Slobin (1994). The participants are shown a copy of the picture book; they are told in advance that they are going to be asked to tell a story; they first go through looking at the book, picture-by-picture and are asked to tell the story to a naive addressee (without visual access to the pictures), while again going through picture by picture form beginning to end, with no time limit. The investigator works with each subject individually, and makes an audio recording of the story.

\subsection{Data Coding}

All sessions of this complex oral production task were audiotaped, then entirely transcribed according to the CHAT transcription format (Mac Whinney 2000). The elicited narratives from participants were segmented into clauses. Each clause was accompanied by an elaborate coding in which semantic information (Manner, Cause, Path and deictic Path) in several parts of speech (verbs, satellites and adverbs) was coded. In order to have a complete picture of the spatial domain in the narratives, general static location clauses were also counted. The average numbers of clauses in the three informants groups were: 137 for CL1, 96 for CL2, and 130 for FL1. In every motion event clause, the following elements were considered: the spatial relation expressed (general dynamic location or change of location), the type of motion semantic components used (Manner, Cause or Path), the locus of the motion semantic components (verbs, satellites or adverbials), and the number and packaging of motion semantic components.

We will now present in more detail the typological characteristics of Chinese and French in respect to Talmy's motion events typology. The way we classify those elements is already a part of the analysis and has a very strong impact on how we understand the results. ${ }^{6}$

In Chinese, the Path semantic component can be encoded in verbs and satellites. Path verbs can be divided in four sub-classes in respect of their combinational properties (Kan 2010). ${ }^{7}$ The first is composed of the two deictic verbs: 来 lái "come" and 去 qù "go". These Path verbs are oriented with respect to an Origo, a point of reference or "zero point" of the system of localization (Bühler 1982). When 来 lái "come" and 去 qù "go" occur after another Path verb, they are considered to be satellites (出来 $\left[\mathrm{V}_{\text {Path }}+\mathrm{S}_{\text {Path }}\right]$ ). The second subclass is another closed class of nine items: 上 shàng "ascend", 下 xià "descend", 进 jìn “enter", 出 chī “exit”, 回 huí “return”, 过 guò “cross”, 起 qì “ascend”, 开 $k \bar{a} i$ "away", and 到 dào "arrive". As full verbs, they occur alone (except for 开 $k \bar{a} i$ "separate") or can be followed by 来 lái "hither" and 去 qù “thither" (翻过

\footnotetext{
${ }^{6}$ About the Figure's syntactic positions, see Jerry Packard "Space, Time and Assymmetry in Chinese" in this volume; about Ground expression, see Yao Ruoyu "Expression of the inclusion relationship in contemporary Chinese" and Feng Shengli "The Prosodically Motivated Localizers in Classical Chinese" in this volume.

${ }^{7}$ For a proposal of motion morphemes order in Chinese, see Lin (2011).
} 
fän-guò $\left.\left[\mathrm{V}_{\text {Path }}+\mathrm{S}_{\text {Path }}\right]\right)$. The third is an open class of verbs like: 掉 diào "fall", 升 shēng “rise", 退 tuì “draw back", 围 wéi "surround". They can be followed by the second type of Path verb, but not directly by deictic Path verbs (掉下 diàoxià $\left[\mathrm{V}_{\text {Path }}+\mathrm{S}_{\text {Path }}\right]$, *掉来 diào-lái $\left.\left[\mathrm{V}_{\text {Path }}+\mathrm{S}_{\text {Deixis }}\right]\right)$. The forth is another open class of verbs like: 跟 gēn “follow", 追 zhū “pursue", 绕 rào “circle”, 逃 táo "escape". This class of verb can occur alone or can also be followed by the first or the second class of verbs, or both (逃出去 táo-chī-qu $\left[\mathrm{V}_{\text {Path }}+\mathrm{S}_{\text {Path }}+\mathrm{S}_{\text {Deixis }}\right]$ ). We have to add to this categorization two classes of satellites that can occur after another verb to form a verb compound: attainment resultatives like 走 zǒu “away", 掉 diào “away", 倒 dǎo "topple"; and, stative resultatives like 远 yuăn "far", and 近 jìn "near". The Manner semantic component can occur in verbs and adverbs. The Manner verbs can occur alone, or followed by Path satellites (跳出 tiào-ch $\bar{u}\left[\mathrm{~V}_{\text {Manner }}+\mathrm{S}_{\text {Path }}\right]$ ). Manner verbs can be divided into two categories: self-agentive verbs, for animated Figures, and non-agentive verbs for inanimate Figures (Lamarre 2003). The Manner adverbs, derived from adjectives, occur before the verb:

（8）他慢慢地走到了这个树丛旁边 $\left[\mathrm{V}_{\text {Manner }}+\mathrm{S}_{\text {Path }}\right]$ tā mànmàn de zŏu-dào le zhè ge shùcóng pángbiān he slow $D_{a d v}$ walk-to $L E$ this $C L$ thicket side "He slowly walked up to this thicket."

The Cause semantic component can only be encoded in verbs. This category includes two types of verbs. They can all be followed by Path satellites. The first category is composed of verbs that intrinsically have a causative semantics and therefore involve a change of location of the Figure: 放 fàng "put", 扔 rēng “throw", 摔 shuāi “project" or 掏 tāo "remove". The second category is composed of all the action verbs that do not involve a systematic change of location of the Figure, but can be followed by Path satellites to form dynamic predicates. The possible combinations are numerous: 叫 jiào “call”, 踢 $t \bar{l}$ “kick”, 吓 xià “scare", 摇 yáo “shake" etc.:
（9）梅花鹿 把 小狗 也 踢 了下去 $\left[\mathrm{V}_{\text {Cause }}+\mathrm{S}_{\text {Path }}+\mathrm{S}_{\text {Deixis }}\right]$ méihuālù bă xiăo gǒn yě tī le xià-qu deer BA little dog also kick LE down-thither "The deer also kicked down the dog."

In French, the Path semantic component can be encoded in verbs and satellites. Path verbs can be divided in two sub-classes depending on their semantic properties, deictic Path verbs (venir "to come") and non-deictic Path verbs (s'approcher "to get closer to"). Path satellites can also be divided into two sub-classes: prefixes and verbal particles (Kopecka 2004). 
In their most simple form, verbs of Manner or Cause express activities without inherent time limitation or a motion semantic component. Some prefixes can specify the spatio-temporal phase of the event, and transform activity verbs into dynamic verbs. For example, the em- prefix indicates the source of motion (emporter "take away"), while the prefix $a(p)$ - indicates the goal of motion (apporter "bring"); they both imply location changes. Path verbs can also be prefixed. In this case, another Path component is added to the verb root. For example, the re-prefix in revenir "to come back" denotes a return motion to the Ground. A few Cause verbs can take up to two prefixes (remporter "take awayback"). ${ }^{8}$ The verbal particles are adverbs or prepositions (hors "out of", jusqu'à "all the way to", sur "on", sous "under" or dans "in") which are contextually dynamic and have a particular function. The Path component they contain completes the verb to form a predicate which can express a change of location.

(10) Le petit garçon saute dans la cour $\left[\mathrm{V}_{\text {Manner }}+\mathrm{S}_{\text {Path }}\right]$ the little boy jump into the yard

"The little boy jumps in the yard."

This predicate has two possible interpretations: "jump up and down in the courtyard" or "jump into the courtyard". According to the context of the story, we can conclude that what the informant meant is the second option. These particles add a Path component to the Manner verb and create a change of location where the verb alone would express a general dynamic location without boundary crossing. The Manner semantic component can occur in verbs and adverbs. The Manner verbs can occur alone, with Manner adverbs, and Path satellites. There are verbs that lexicalize Manner and Path semantic components, like: grimper "to climb", se hisser "to haul up", escalader "to climb", s'envoler "to fly away", dégringoler "to tumble down", dévaler "to hurtle down", plonger "to dive". These verbs evolved from Old French to the current lexicalization to form single units that cannot be analyzed as prefixed verbs. The Cause semantic component can only be encoded in verbs.

\subsection{Research Questions and Hypothesis}

On the basis of the frog story narrative task, our first aim was to generate the overall patterns characterizing the distribution of semantic components of motion events in French and Chinese L1. According to Talmy (1985, 1991, 2000b), these two languages are respectively verb-framed and satellite-framed; this typological difference should have great impact on different aspects of the lexicalization used by those speakers. Therefore, we expect that Chinese L1 speakers, compared to French L1 speakers should (a) encode more semantic components in dynamic predicates; (b) pay more attention to the expression of co-events; (c) encode co-events in verbs and framing-events in satellites;

\footnotetext{
${ }^{8}$ For a complete description of motion prefixes, see Kopecka (2004: 179).
} 
(d) and according to Slobin's (1987, 1996a) "thinking for speaking" hypothesis, the Chinese rhetorical style should lead native speakers to express more changes of location than general static locations.

Slobin (1996b) argues that "the attention to different kinds of events and experiences paid by each native language is exceptionally resistant to restructuring in adult second-language acquisition". Our second aim is therefore to investigate the following hypothesis: when using their L2, French learners of Chinese rely on how motion events are structured in their L1, and they have to master a new lexicalization process to be able to utilize the L2 in a native way; this new conceptual elaboration should appear at the conceptualization level during speech production (Levelt 1989).

\section{Results}

\subsection{Spatial Predicates}

The type of discourse analyzed is a fictional story quest. It was therefore expected that there would be many non-spatial clauses. During the elicitation task, informants must pay attention to many fields other than space, such as time and events. Nevertheless, we notice that the three groups did not give the same importance to the spatial domain when they retold the frog story. The CL1 encoded $31.4 \%$ of spatial clauses. The remaining 2 groups (FL1 and CL2) encoded $27.9 \%$ and $26.8 \%$, respectively.

Due to the nature of the story, it was also expected that compared to general static and dynamic locations, changes of location would dominate the story, as they are needed to describe the actions of the protagonists and to go further into the story: our study confirmed this across all groups. Despite this general similarity, speakers still show different strategies.

Focusing on spatial clauses, as detailed in Fig. 1, we can see that the CL1 speakers express $47.8 \%$ of changes of location and $35 \%$ of general static locations, whereas FL1 speakers utilize the opposite strategy, expressing $40.1 \%$ of changes of location and $49.8 \%$ of general static locations. There is also a significant difference in general dynamic locations (CL1: 17.2 \%, FL1: 10.1\%),

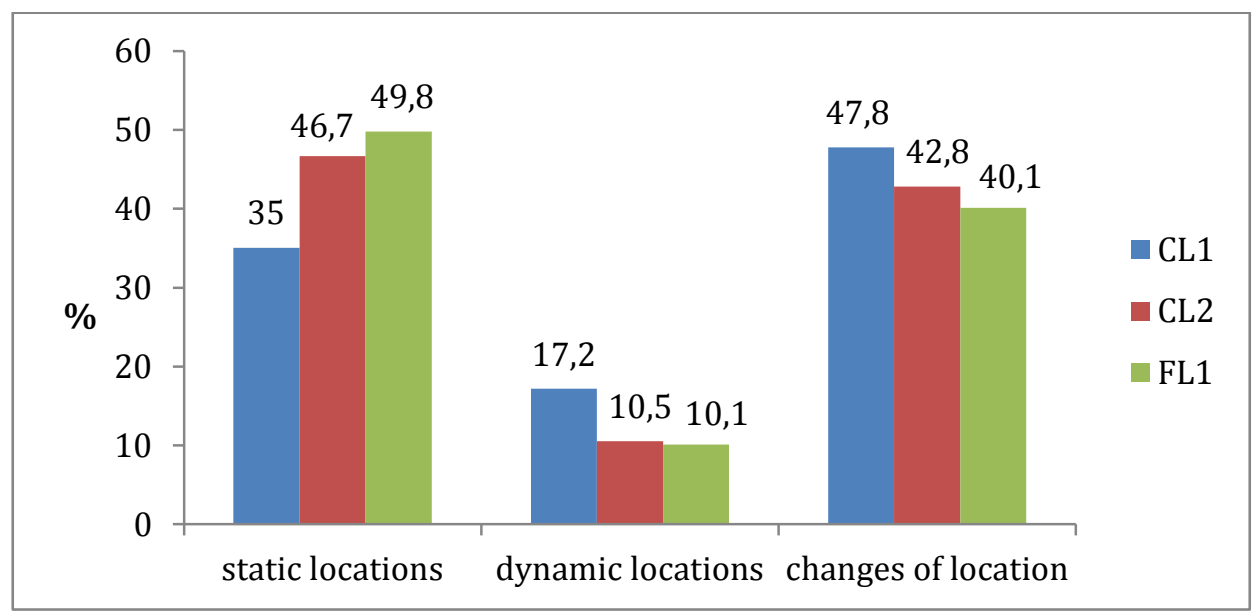

Fig. 1 Spatial predicates 
showing that the CL1 speakers definitely pay more attention to the movement of entities than FL1 do. In this respect, the CL2 speakers clearly follow their L1, expressing more general static locations $(46.7 \%)$ than changes of location $(42.8 \%)$, with also a low rate of general dynamic locations $(10.5 \%)$.

CL2 speakers sometimes express in a static or non-spatial way what is described as dynamic by CL1 speakers. Consider a specific example with the appearance of the deer in the story. At this point in his search, the little boy sits on a rock, calling for his frog. Suddenly, a deer stands out behind the rock and takes the boy into his horns. In the CL1 narratives, the latter action is described as dynamic $62.5 \%$ of the time (with directional resultatives like 顶起 dingq “carry up on the head", 举起 jŭqu “lift up"...) or is totally ignored, but is never described as static:
(11) 孩子 被 梅花鹿顶起
háizi bèi méihuālù dìng-qŭ
child BEI deer carry up on the head-up
"The boy is picked up by the deer on its head."

The CL2, as well as FL1, use very few dynamic descriptions, $12.5 \%$ and $16.6 \%$ respectively, and use rather elaborate descriptions of static scene-setting (CL2: $75 \%$, FL1: $66.6 \%$ ). The footprint of French habits is still obvious in the CL2 speaker's description of events:

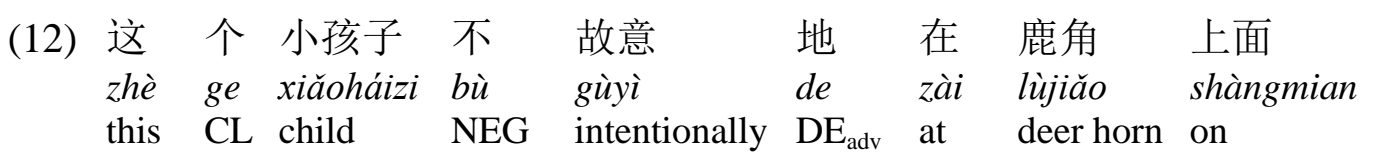
"The child is on the deer's horns by mistake."

\subsection{Semantic Components density}

By far the most common lexicalization pattern in the CL1 group is the one encoding two semantic components, $\left[\mathrm{V}_{\text {co-event }}+\mathrm{S}_{\text {Path }}\right],\left[\mathrm{V}_{\text {Path }}+\mathrm{S}_{\text {Deixis }}\right]$ or $\left[\mathrm{V}_{\text {co- }}\right.$ event $\left.+\mathrm{S}_{\text {Deixis }}\right]$ in dynamic predicates at $42.9 \%$ :
(13) 突然从洞 里面 钻出 了一只老鼠 $\left[\mathrm{V}_{\text {Manner }}+\mathrm{S}_{\text {Path }}\right]$

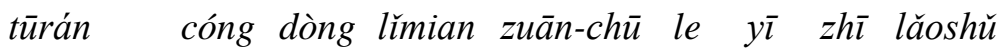 suddenly from hole in creep-out LE one CL rat "Suddenly, a rat crept out of the hole"

Single component and three or more component predicates represent $31.3 \%$ and $25.8 \%$ respectively, as illustrated in Fig. 2. 


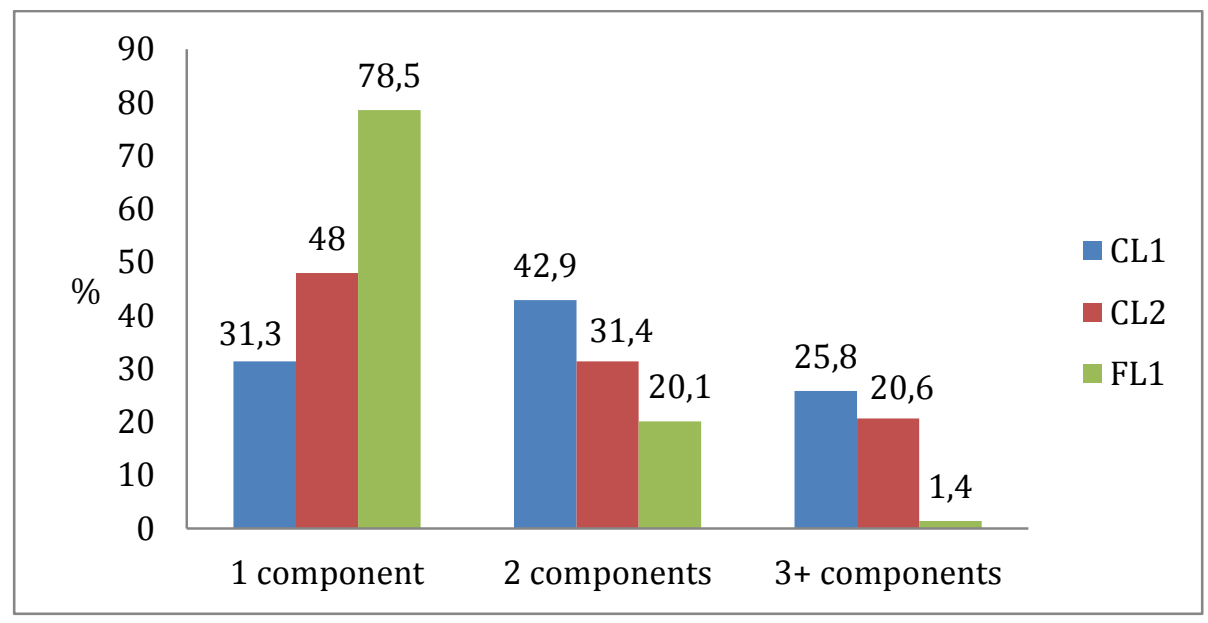

Fig. 2 Component density

As expected, the most frequent packaging in FL1 is a single component in the predicate $(78.5 \%)$ :

(14) un petit animal sort du trou $\left[\mathrm{V}_{\text {Path }}\right]$ a small animal exit from hole

"a small animal comes out of the hole"

Because of its lexicalization pattern characteristics, only a few verbs (such as grimper "to climb" or emmener "to take away") lexicalize two semantic components and only very few satellites (jusqu'à "all the way to") or adverbials (doucement "slowly") occur to build up the dynamic predicates $(20.1 \%)$. Predicates with three or more components are very rare $(1.4 \%)$ and are limited to the use of a few verbs such as remporter "take back" with two prefixes $(r$ back, em- away).

CL2 speakers show a tendency to get closer to the lexicalization pattern of their target language while preserving L1 characteristics. Indeed, on one hand, they use many single component predicates (48 \%) just as in FL1, and in contrast they also utilize a large number of packaging with two and three or more components (31.4\% and $20.6 \%$ respectively) like in CL1.

\subsection{Semantic Components Focus}

If we consider all dynamic predicates, we observe, as shown in Fig. 3, that the overall proportion of semantic components (in verbs, adverbs, and satellites) is the same among all three groups. The Path semantic component is by far the most common, followed by Manner and Cause. Apart from this common trend, which is influenced by the content of the story, there are major differences between the three groups.

For the Manner component, there is a substantial gap between CL1 $(27.7 \%)$ on one hand and the other two groups FL1 (17.2 \%) and CL2 (17.7\%). The lexicalization pattern and accessibility of Manner in Chinese with the resultatives explains why $\mathrm{S}$-language speakers rely so much on this component, and why they consider Manner of motion to be an inherent component of motion events. 


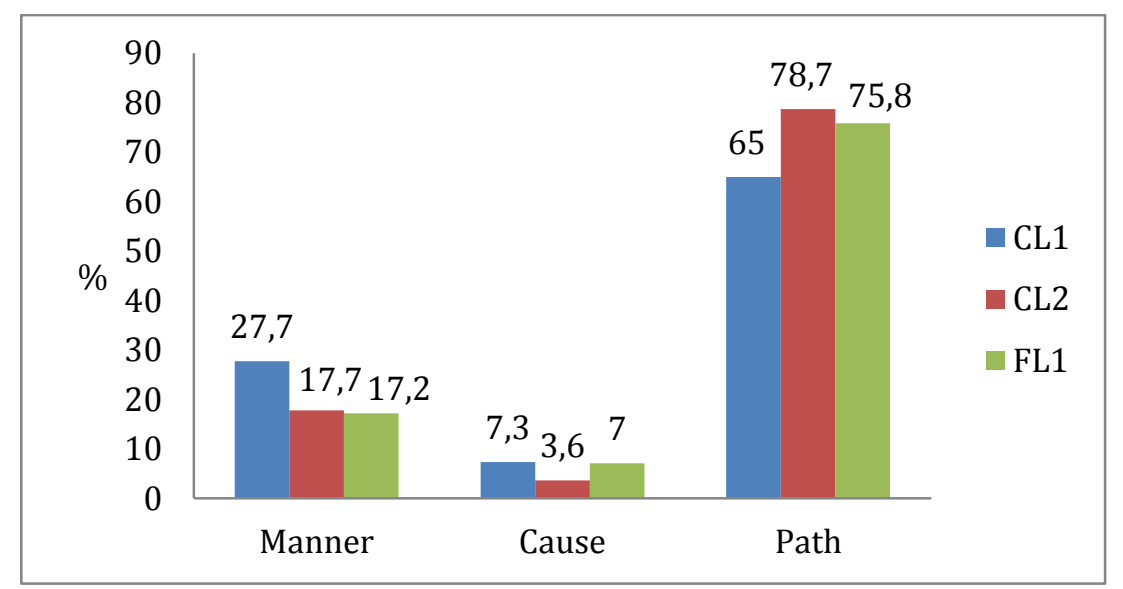

Fig. 3 Semantic components focus

The French lexicalization pattern allows V-language speakers to encode Manner of motion in the case of a general dynamic location, when the Figure does not cross the Ground's boundaries, but not in case of a change of location (except if the Path is encoded in a satellite, which leaves the verb slot available for Manner) which is the most common type of event in this kind of narrative. As a result, French typological properties determine the low rate of Manner of motion encoded by the speakers (see examples (13) and (14) above). For the Cause component, the rate is low int the three groups, but they show the same overall tendency as the Manner component between CL1 and CL2.

For the Path component, there is also a striking difference between CL1 (65\%), FL1 (75.8\%) and CL2 (78.7 \%). The lexicalization pattern with the Path component encoded in the verb also explains why the V-language speakers rely more on the framing event in event descriptions than S-language speakers. It is therefore clear that the learners follow the habits of their mother tongue for the expression of Manner and Path.

\subsection{Semantic Components Locus}

Having studied the proportions of the semantic components used, we will now focus on their distribution among the linguistic surface components.

If we first consider the distribution of semantic components within the verbs (excluding satellites and adjuncts), we can see in Fig. 4 that the CL1 essentially use this linguistic component to encode co-events (Manner: 46.2\%, Cause: $14.5 \%$ ) rather than framing-events (Path: $39.3 \%$ ), while the lexicalization in FL1 is exactly the opposite (Manner: $14.2 \%$, Cause: $8.2 \%$, Path: $77.6 \%$ ).

Learners obviously use the same lexicalization pattern as their L1 (Manner: $25.5 \%$, Cause: $6.3 \%$, Path: $68.2 \%$ ), even if they encode more Manner components in the verb than in FL1.

Looking at the study more holistically, including satellites and adjuncts, as detailed in Fig. 5, we come to several conclusions. For co-events, only the Manner component can be distributed over two different linguistic components; therefore we will not repeat what was said about Cause in Fig. 4. 


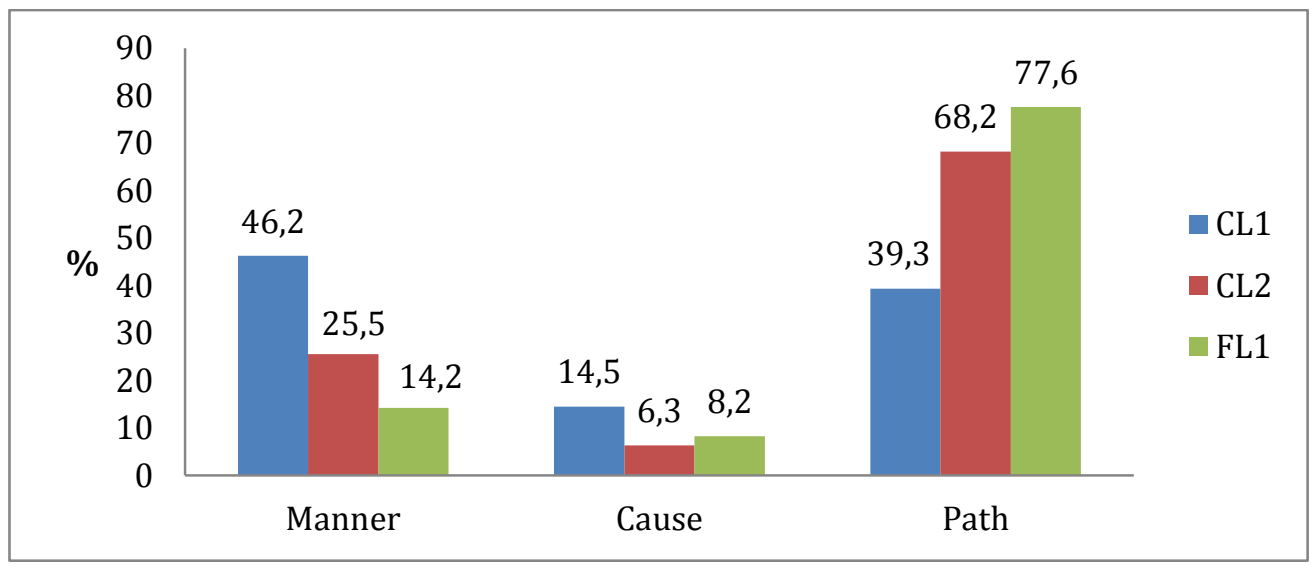

Fig. 4 Semantic components in verbs

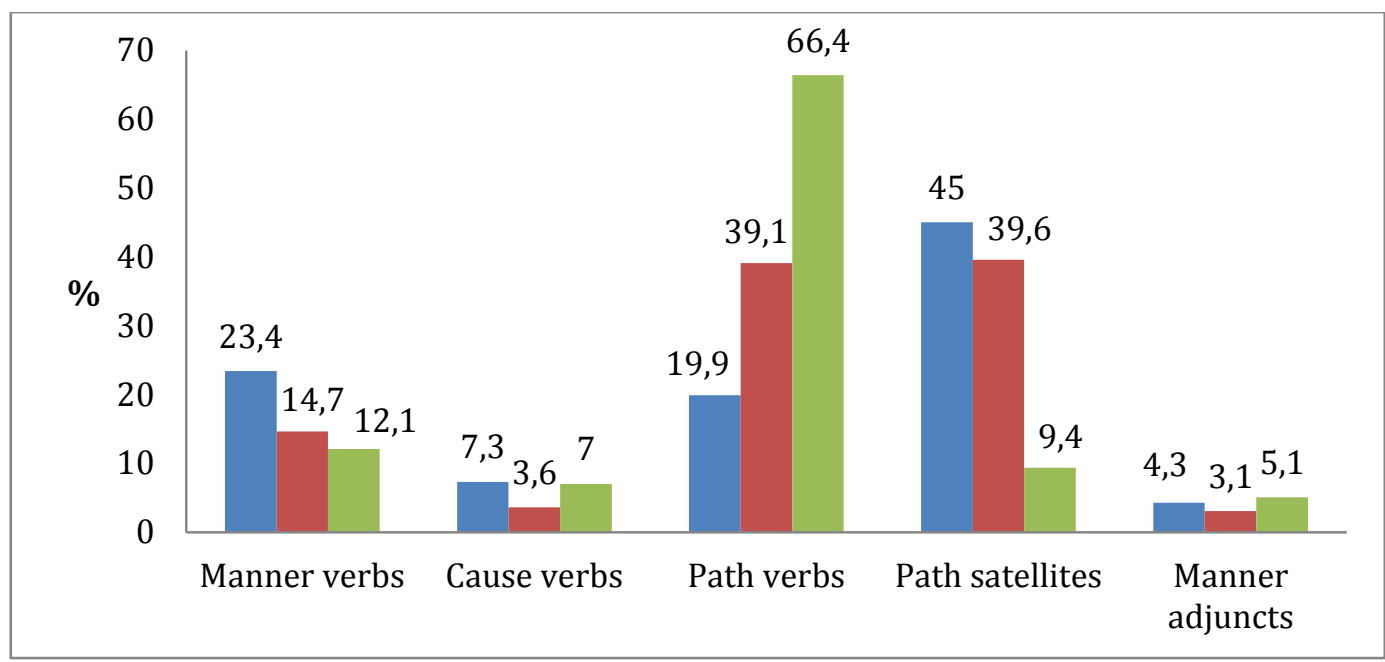

Fig. 5 Semantic components locus

The Manner semantic component can be encoded in verbs (single verb or resultative's $\mathrm{V}_{1}$ ) or in adjuncts although rarely occurs in the three groups. CL1 speakers rely on Manner verbs to encode this component, and therefore do not use many adjunct expressions $(4.3 \%)$; while FL1 speakers neglect to encode Manner components in verbs, but don't fill this gap with this other possible linguistic component $(5.1 \%)$. The CL2 speakers follow the global trend of their L1, encoding less Manner in verbs that CL1, and less Manner in adjuncts that FL1 (3.1\%), possibly for syntactic complexity reasons.

The Path can be encoded in verbs (single verbs or in a resultative's $\mathrm{V}_{1}$ ) or in satellites $\left(\mathrm{V}_{2}\right.$ or/and $\left.\mathrm{V}_{3}\right)$. The CL1 largely favor the use of satellites (45\%), rather than verbs $(19.9 \%)$ for this component:

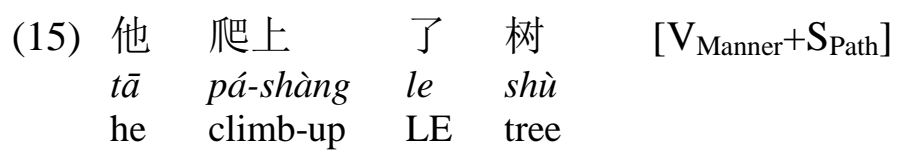

"He climbed up the tree."

This distribution is exactly the opposite in FL1 (9.4\% and $66.4 \%$ respectively): 
(16) il monte sur un locher $\left[\mathrm{V}_{\text {Path }}\right]$
he climb on a
"He climbs up a rock."

The CL2 speakers commonly use both surface components to encode the Path (satellites: $39.6 \%$, verbs: $39.1 \%$ ):

$\begin{array}{lllllll}\text { (17) 他们 上 } & \text { 了 } & \text { 这 } & \text { 棵 } & \text { 树 } & \left.\text { [ } \mathrm{V}_{\text {Path }}\right] \\ \text { tāmen shàng } & l e & z h \grave{e} & k \bar{e} & \text { shù } & \\ \text { they ascend } & \mathrm{LE} & \text { this } & \mathrm{CL} & \text { tree } & \\ \text { "They went up this tree." } & & \end{array}$

We can therefore see that, by encoding Path in satellites, CL1 leaves the $\mathrm{V}_{1}$ slot free for the Manner and Cause components, while the CL2 follow the trend of their native language to encode the Path in large quantities in the $\mathrm{V}_{1}$ position, the resultative head, as the only semantic component of the clause. However, learners also show their acquisition process by using many Path satellites. Their learner's variety presents characteristics of their L1 and L2 simultaneously.

\subsection{Semantic Components Packaging}

The complexity of dynamic predicates demonstrated by learners shows an evolution towards the target language (see section 4.2). However, we now see that the choices of semantic components in this packaging vary greatly between CL1 and CL2. For example, we can see from Fig. 6 that in the case of two or three component predicates (distributed among verbs and satellites), the CL1 speakers encode Manner or Cause components at $70.3 \%$ :
（18）小明 从 树上 摔了下来 $\left[\mathrm{V}_{\text {Manner }}+\mathrm{S}_{\text {Path }}+\mathrm{S}_{\text {Deixis }}\right]$ Xiăo Míng cóng shù shang shuāi le xià-lai Xiao Ming from tree on tumble LE down-hither "Xiao Ming tumbled down from the tree."

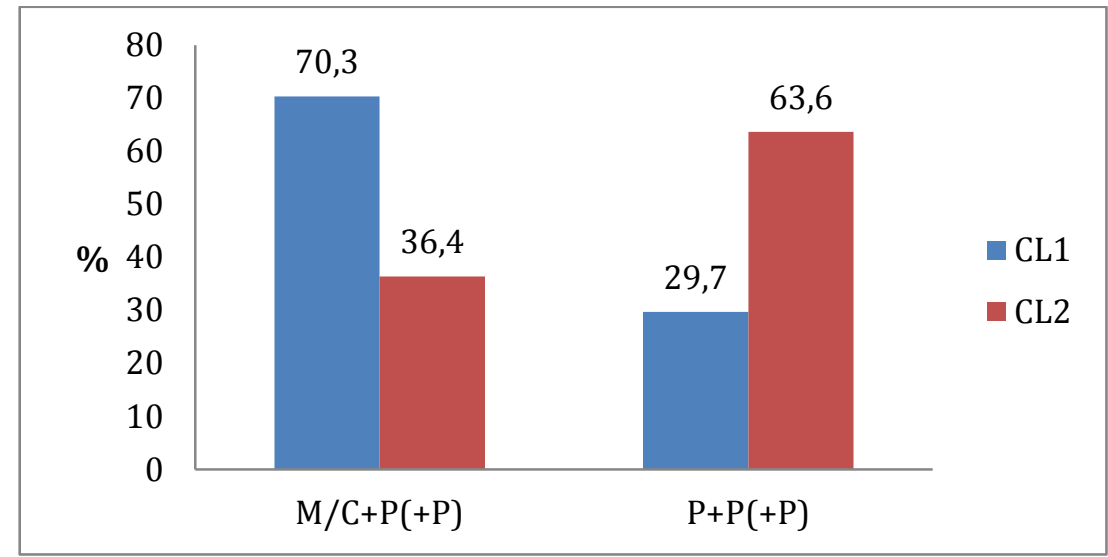

Fig. 6 Semantic components in resultatives 


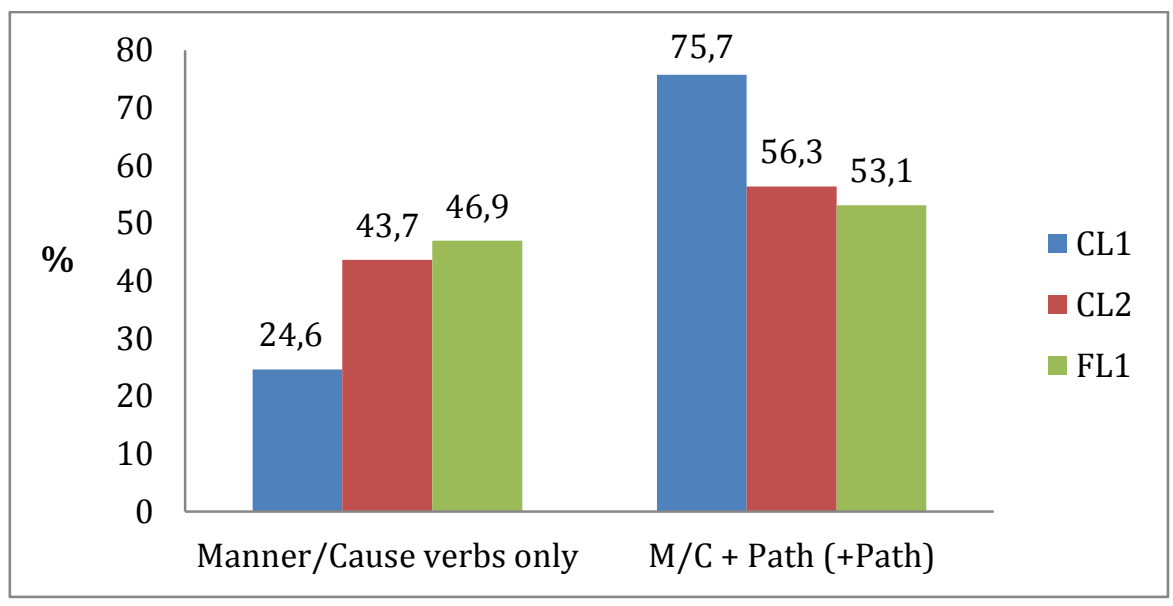

Fig. 7 Manner/Cause verbs and Path semantic components combinations

This proportion falls down to $36.4 \%$ in CL2. Learners use the two or three components packaging only to encode several times the Path component up to $63.6 \%$ :
(19) 这个小狗从窗户 掉下来 $\left[\mathrm{V}_{\text {Path }}+\mathrm{S}_{\text {Path }}+\mathrm{S}_{\text {Deixis }}\right]$
zhè ge xiăo gǒu cóng chuānghu diào-xià-lai
this CL small dog from window fell-down-hither

"The small dog fell down from the window."

This kind of packaging represents only $29.7 \%$ in CL1.

Learners are capable of producing very rich dynamic predicates; however, their choice is still rather on the framing-event, according to the characteristics of their native language.

In addition, as can be seen from Fig. 7, the CL1 generally do not encode single Manner or Cause components in verbs (24.6\%), they prefer to use a two or three component packaging to encode co-events in the verb and Path within one or two satellites $(75.7 \%)$ for changes of location. However, CL2, like FL1, encode more single Manner or Cause components in verbs $(43.7 \%)$, and use much simpler packaging with one or two Path satellites $(56.3 \%)$ than CL1. This means that when S-language speakers conceive Manner as part of motion events in changes of location, the V-language speakers interpret Manner of motion more as an activity that take place in a specified spatial location (Slobin 2000, 2004). When they need to express change of location, they rely solely on the framing-event, the Path component.

\section{Discussion and Conclusion}

The first remark that we can make after analyzing the narratives is that the FL1 speakers placed less importance on the spatial domain than the CL1 speakers did. The former describe the actions and the feelings of the boy and the dog in the story and where the numerous entities of the story are; while the latter give more details about how and where the protagonists go. More specifically, FL1 speakers fall back on general static locations and express fewer changes of 
location, and significantly less general dynamic locations than CL1. They tell the story in a more static way, where Chinese speakers would tell it in a more dynamic way. This result is consistent with what Slobin (1996a, b, 1997, 2000, 2004) observed for English as an S-language compared to Spanish as a Vlanguage. Slobin found that S-language speakers devote more attention to motion with more detailed description of trajectories (generally also with Manner verbs) than V-language speakers who, by contrast, are more concerned with establishing the static scene-setting in which trajectories of movement could be inferred. Slobin proposed that those two kinds of languages differ systematically in what he calls the "rhetorical style", or the ways in which events are analyzed and described in discourse. He also proposed that it is determined by the "ease of processing", the relative accessibility of various means of expression, such as lexical items and construction types. In this respect, the CL2 are close to the FL1, they present the same rhetorical style as French native speakers.

The analysis of the narratives clearly shows great differences in the expression of motion events between Chinese as a S-language and French as a V-language. Supporting Talmy's typology $(1985,1991,2000 \mathrm{~b})$, we saw that the lexicalization pattern of these languages has a major influence on the semantic components' density, focus, locus and packaging in narratives. In all these aspects, the CL2 speakers showed some characteristics of their L1 lexicalization pattern, while in some respects also getting closer to their target language.

First of all, from the semantic components density point of view, we showed that CL2 dynamic predicates are not as complex as the ones CL1 encoded. Almost half of their dynamic predicates encode only one motion component, while CL1 speakers usually encode two components. Secondly, CL2 encoded less Manner and Cause, but more Path components than the CL1. The information they chose to emphasize is similar to that of the L1 group. Thirdly, considering the component locus, Talmy 2000b (128-9) argues that the constituent type used to encode a component of meaning influences its salience to attention: a semantic component can be "backgrounded" by expression in the main verb complex; or "foregrounded" when encoded elsewhere, in any kind of adjunct. While the latter perspective attracts more direct attention, the component in the former tends to be expressed more readily, in a stylistically more colloquial utterance that has a low cognitive cost. In a change of location type of motion event, the French language does not allow the Manner semantic component to be encoded in the main verb; it can however be encoded in a gerund or a prepositional phrase. However FL1 narrative analysis showed that the native speakers did not fill in the lack of background information by foregrounding the Manner. In CL2, the semantic component of Manner is quite rarely encoded in verbs, but the learners, as their L1 speakers, did not fill this information gap in these linguistic components with adverbial adjuncts. The influence of their L1 lexicalization pattern is obvious. Finally, in respect to component packaging, CL1 showed the typical semantic component distribution of an S-language, with co-events in verbs and framing-events in satellites. The CL2 complex resultative predicates usually encoded only two or three Path components; co-events, when encoded, are in single verbs. This characteristic confirms Slobin's rhetorical style hypothesis: learners distinguished on one hand the Manner component encoding for general dynamic location without boundary crossing, and the Path component on the other hand for changes of location. 
They did not associate Manner of motion with changes of location, as the FL1 lexicalization pattern leads speakers to do, while CL1 encoded Manner in these two different dynamic predicates.

We will end this conclusion by using Levelt's discourse production model to explain and sum up the characteristics of the CL2 narratives. Levelt (1989) proposed a discourse production model that details the operations involved and how they are organized in language use. The model gives a representation of what happens in the speaker's brain, from the intention of communication to the articulation of speech. For native speakers, preverbal message conceptualization (high level activity) requires constant attention, while formulation and articulation operations are automated (low level activities). For L2 learners, even partial mastery of these last two operations can potentially disrupt the high level activity. The CL2 narrative analysis reveals few idiosyncratic phenomena on the syntactic level. The formulation process (transition from the conceptual to the linguistic level) is carried out without much difficulty, and they demonstrate good declarative knowledge. The difference between the Chinese native speakers and learners is rather at the conceptualization level, when the speaker defines their communicative intentions, and even more so when selecting the necessary information before it is linearized. Learners' narratives differ from those of CL1 speakers in respect to the selection of semantic components in dynamic predicates. Lexicalization of motion events in Chinese differs vastly from French, and learners' preverbal message formation is still influenced greatly by their L1 grammaticalized forms when it comes to quantity, choice and distribution of information.

\section{References}

Aikhenvald, A.Y., and R.M.W. Dixon. 2006. Serial verb constructions. Oxford: Oxford University Press.

Ameka, Felix K., and James Essegbey. 2001. Serialising languages: Verb-framed, satellite-framed or neither? In African comparative and historical linguistics: Proceedings of the 32nd annual conference on African linguistics, ed. L. Hyman and M. Ian, 1-12. Lawrenceville: Africa World Press.

Ameka, Felix K., and James Essegbey. 2006. Elements of the grammar of space in Ewe. In Grammars of space: Exploration in cognitive diversity, ed. Stephen C. Levinson and David Wilkins, 359-399. Cambridge/New York: Cambridge University Press.

Arslangul, Arnaud. 2001. Les relations spatiales dynamiques en chinois langue étrangère. Sarrebruck: Editions universitaires européennes.

Aske, Jon. 1989. Path predicates in English and Spanish: A closer look. In Proceedings of the fifteenth annual meeting of the Berkeley Linguistics Society, 1-14. Berkeley: Berkeley Linguistics Society.

Bartning, Inge. 1997. L'apprenant dit avancé et son acquisition d'une langue étrangère. Tour d'horizon et esquisse d'une caractérisation de la variété avancée. AILE 9: 9-50.

Becker, Angelika, and Mary Carroll. 1997. The acquisition of spatial relations in a second language. Amsterdam/Philadelphia: John Benjamins.

Berman, Ruth A., and Dan Slobin I. 1994. Relating events in narrative: A crosslinguistic developmental study. Hillsdale: Lawrence Erlbaum Associates.

Bloom, Paul, Mary A. Peterson, and Lynn Nadel. 1996. Language and space. Cambridge, MA: MIT Press. 
Bühler, Karl. 1982. The deictic field of language and deictic words. In Speech, place, and action: Studies in deixis and related topics, ed. Robert J. Jarvella and Wolfgang Klein, 9-30. Chichester/New York/Brisbane/Toronto/Singapore: Wiley.

Carroll, Mary, and Christiane von Stutterheim. 1993. The representation of spatial configurations in English and German and the grammatical structure of locative and anaphoric expressions. Linguistics 31(6): 1011-1041.

Chao, Yuen Ren. 1948. Mandarin primer, an intensive course in spoken Chinese. Cambridge, MA: Harvard University Press.

Chao, Yuen Ren. 1968. A grammar of spoken Chinese. Berkeley: University of California Press.

Chen, Liang. 2005. The acquisition and use of motion event expressions in Chinese. University of Louisiana at Lafayette, thesis.

Chen, Liang, and Jiansheng Guo. 2009. Motion events in Chinese novels: Evidence for an equipollently-framed language. Journal of Pragmatics 41: 1749-1766.

Chen, Liang, and Jiansheng Guo. 2010. From languages structures to language use: A case from Mandarin motion expression classification. Chinese Language and Discourse 1(1): 31-65.

Ding, Shengshu 丁声树. 1961. Xiàndài hànyŭ yŭfă jiănghuà 现代汉语语法讲话 [Lectures on modern Chinese grammar]. Běijīng 北京: Shāngwù yìnshūguăn 商务印 书馆 [The commercial press].

Fan, Xiao 范晓. 1998. Hànyǔ de jùzi lèixíng 汉语的句子类型 [Chinese sentence types]. Taiyuan 太原: Shūhăi chūbănshè 书海出版社 [Sea of Books Press].

Feng, Li. 2001. Origine et évolution du complément directionnel complexe en chinois. Cahiers de Linguistique Asie Orientale 30(2): 179-214.

Gao, Zengxia 高增霞. 2006. Xiàndài hànyǔ liándòngshì de yǔfăhuà shìjiăo 现代汉语连 动式的语法化视角 [Grammaticalization perspective in modern Chinese serial verb construction]. Běijīng 北京: Zhōngguó dàng'àn chūbănshè 中国档案出版社 [Chinese Archives Press].

Hendriks, Henriëtte. 1998. Comment il monte le chat ? En grimpant ! L'acquisition de la référence spatiale en chinois, français et allemand LM et LE. AILE 11: 147-190.

Hickmann, Maya, and Stéphane Robert. 2006. Space in languages: Linguistic systems and cognitive categories. Typological studies in language. Amsterdam: John Benjamins.

Hickmann, Maya, and Henriëtte Hendriks. 2010. Typological constraints on the acquisition of spatial language in French and English. Cognitive Linguistics 21(2): 189-215.

Ji, Yingli, Henriette Hendriks, and Maya Hickmann. 2011. Children's expression of voluntary motion events in English and Chinese. Journal of Foreign Languages 外 国语 34(4): 2-19.

Kan, Zhehua 嘬哲华. 2010. Hànyǔ wèiyí shìjiàn cíhuìhuà de yǔyán lèixíng tànjiū 汉语 位移事件词汇化的语言类型探究 [Language typology exploration of motion events conflation in Chinese]. Dāngdài yǔyánxué 当代语言学 [Contemporary Linguistics] 12(2): 126-135.

Kopecka, Anetta. 2004. Étude typologique de l'expression de l'espace: localisation et déplacement en français et en polonais. $\mathrm{PhD}$ dissertation. Université Lumière Lyon 2.

Lamarre, Christine. 2003. 汉语空间位移事件的语言表达一一兼论述趋式的几个问 题 Hànyǔ kōngjiān wèiyí shìjiàn de yǔyán biăodá—jiān lùn shùqūshì de jǐ gè wèntí [The linguistic encoding of motion events in Chinese]. 现代中国语研究 Xiàndài Zhōngguó yŭ yánjiū [Contemporary Research in Modern Chinese] 5: 1-18.

Lamarre, Christine. 2007. The linguistic encoding of motion events in Chinese: With reference to cross-dialectal variation. In Typological studies of the linguistic expression of motion events, volume 1: Perspective form East and Southeast Asia, ed. 
Christine Lamarre and Toshio Ohori, 3-33. Tokyo: Center for Evolutionary Cognitive Sciences at the University of Tokyo.

Levelt, Willem J.M. 1989. Speaking: From intention to articulation. Cambridge, MA/London: MIT Press.

Levinson, Stephen C. 2003. Space in language and cognition: Explorations in cognitive diversity. Cambridge/New York: Cambridge University Press.

Levinson, Stephen C., and David Wilkins. 2006. Grammars of space: Exploration in cognitive diversity. Cambridge/New York: Cambridge University Press.

Li, Fengxiang. 1997. Cross-linguistic lexicalization patterns; Diachronic evidence form verb-complement compounds in Chinese. Sprachtypol, Univ Forsch 50(3): 229-252.

Li, Charles N., and Sandra A. Thompson. 1981. Mandarin Chinese: A functional reference grammar. Berkeley: University of California Press.

Liang, Yingfeng 梁银峰. 2007. Qūxiàng dòngcí de yŭfăhuà 趋向动词的语法化 [Grammaticalization of directional verbs]. Shanghai 上海: Xuélín chūbănshè 学林出 版社 [Academia Press].

Lin, Jingxia. 2011. The encoding of motion events in Chinese: Multi-morpheme motion constructions. $\mathrm{PhD}$ dissertation, Stanford University.

Lorenzo Rosselló, Cristina de. 2002. Les relations temporo-aspectuelles dans le récit oral en français et en castillan, langues premières et langues étrangères. Etude transversale du stade ultime de l'acquisition d'une langue étrangère. $\mathrm{PhD}$ dissertation, Université Paris 10.

Lü, Shuxiang 吕叔湘. 1980. Xiàndài hànyǔ bābăicí 现代汉语八百词 [The eight hundred words of contemporary Chinese]. Běijīng 北京: Shāngwù yìnshūguăn 商务 印书馆 [The Commercial Press].

Mac Whinney, Brian. 2000. The CHILDES project: Tools for analysing talk. Mahwah: Lawrence Erlbaum Associates.

Mayer, Mercer. 1969. Frog, where are you? New York: Dial Books.

Packard, Jerome L. 2000. The morphology of Chinese. Cambridge/New York/Melbourne: Cambridge University Press.

Peyraube, Alain. 2006. Motion events in Chinese. A diachronic study of directional complements. In Space in languages: Linguistic systems and cognitive categories, ed. Maya Hickmann and Stéphane Robert, 121-135. Amsterdam/Philadelphia: John Benjamins.

Pourcel, Stéphanie, and Anetta Kopecka. 2005. Motion expression in French: Typological diversity. Durham \& Newcastle Working Papers in Linguistics 11: 139153.

Schaefer, R.P. 1986. Lexicalising directional and nondirectional motion Emai. Studies African Linguistics 17(2): 177-198.

Senft, Gunter. 2006. Prolegomena to a Kilivila grammar of space. In Grammars of space: Exploration in cognitive diversity, ed. Stephen C. Levinson and David Wilkins, 206-229. Cambridge/New York: Cambridge University Press.

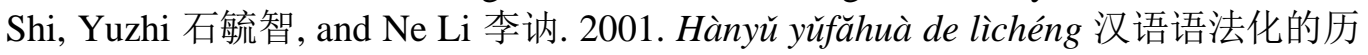
程 [Chinese grammaticalization course]. Běijīng 北京: Běijīng dàxué chūbănshè 北 京大学出版社 [Beijing University Press].

Slobin, Dan I. 1987. Thinking for speaking. In Proceedings of the thirteenth annual meeting of the Berkeley Linguistics Society, 435-444. Berkeley: Berkeley Linguistics Society.

Slobin, Dan I. 1996a. From "thought and language" to "thinking for speaking". In Rethinking linguistic relativity, ed. John Joseph Gumperz and Stephen C. Levinson, 70-96. Cambridge/New York: Cambridge University Press.

Slobin, Dan I. 1996b. Two ways to travel: Verbs of motion in english and spanish. In Grammatical constructions: Their form and meaning, ed. Shibatani Masayoshi and Sandra A. Thompson, 195-219. Oxford/Toronto: Clarendon Press/Oxford University Press. 
Slobin, Dan I. 1997. Mind, code, and text. In Essays on language function and language type: Dedicated to T. Givón, ed. Joan Bybee, John Haiman, and Sandra A. Thompson, 437-467. Amsterdam/Philadelphia: John Benjamins.

Slobin, Dan I. 2000. Verbalized events: A dynamic approach to linguistic relativity. In Evidence for linguistic relativity, ed. Susanne Niemeier and René Dirven, 107-138. Amsterdam/Philadelphia: John Benjamins.

Slobin, Dan I. 2004. The many ways to search for a frog: Linguistic typology and the expression of motion events. In Relating events in narrative: Typological and contextual perspectives, ed. S. Strömqvist and L. Verhoeven, 219-257. Mahwah: Lawrence Erlbaum.

Slobin, Dan I., and Nini Hoiting. 1994. Reference to movement in spoken and signed languages: Typological considerations. In Proceedings of the twentieth annual meeting of the Berkeley Linguistics Society. Berkeley: Berkeley Linguistics Society.

Talmy, Leonard. 1985. Lexicalisation patterns: Semantic structure in lexical form. In Language typology and semantic description, vol. 3: Grammatical categories and the lexicon, ed. Timothy Shopen, 57-149. Cambridge: Cambridge University Press.

Talmy, Leonard. 1991. Path to realization: A typology of event conflation. In Proceedings of the seventeenth annual meeting of the Berkeley Linguistics Society, 480-519. Berkeley: Berkeley Linguistics Society.

Talmy, Leonard. 2000a. Toward a cognitive semantics, Concept structuring systems, vol. 1. Cambridge, MA: MIT Press.

Talmy, Leonard. 2000b. Toward a cognitive semantics, Typology and process in concept structuring, vol. 2. Cambridge, MA: MIT Press.

Watorek, Marzena. 1998. L'expression de la localisation spatiale dans les productions de locuteurs natifs italophones et francophones, et d'apprenants italophones du français. CALaP 16-17: 17-50.

Zhu, Dexi 朱德熙. 1982. Yǔfă jiăngyì 语法讲义 [Lectures on grammar]. Běijīng 北京: Shāngwù yìnshūguăn 商务印书馆 [The Commercial Press].

Zhu, Dexi 朱德熙. 1985. Yǔfă dáwèn 语法答问 [The questions and answers on grammar]. Běijīng 北京: Shāngwù yìnshūguăn 商务印书馆 [The Commercial Press].

Zlatev, Jordan, and Peerapat Yangklang. 2003. A third way to travel. The place of Thai in motion-event typology. In Relating events in narrative: Typological and contextual perspectives, ed. Sven Strömqvist and Ludo Verhoeven. Mahwah: Lawrence Erlbaum Associates. 